\title{
Transatlantica
}

Revue d'études américaines. American Studies Journal

2| 2017

(Hi)stories of American Women: Writings and Rewritings / Call and Answer: Dialoguing the American West in France

\section{Unfixing the Frame: Visualizing Histories of Transcultural Contact, Exchange \& Performance in Prince Roland Bonaparte's Peaux-Rouges (1884)}

\section{Emily L. Voelker}

\section{OpenEdition}

\section{Journals}

Electronic version

URL: https://journals.openedition.org/transatlantica/10822

DOI: 10.4000/transatlantica.10822

ISSN: 1765-2766

\section{Publisher}

Association française d'Etudes Américaines (AFEA)

\section{Electronic reference}

Emily L. Voelker, "Unfixing the Frame: Visualizing Histories of Transcultural Contact, Exchange \& Performance in Prince Roland Bonaparte's Peaux-Rouges (1884)", Transatlantica [Online], 2 | 2017 , Online since 13 May 2019, connection on 01 February 2023. URL: http://journals.openedition.org/ transatlantica/10822 ; DOI: https://doi.org/10.4000/transatlantica.10822

This text was automatically generated on 1 February 2023.

\section{c)}

Creative Commons - Attribution-NonCommercial-NoDerivatives 4.0 International - CC BY-NC-ND 4.0 https://creativecommons.org/licenses/by-nc-nd/4.0/ 


\title{
Unfixing the Frame: Visualizing
} Histories of Transcultural Contact, Exchange \& Performance in Prince Roland Bonaparte's Peaux-Rouges (1884)

\author{
Emily L. Voelker
}

\section{Introduction}

1 In March 1884 Prince Roland Bonaparte sent a copy of his album, Peaux-Rouges (1884) to the Société d'Anthropologie de Paris, one of the numerous sociétés savantes active in the French capital during the second half of the nineteenth century. ${ }^{1}$ The volume features a sequence of frontal and profile photographs of a group of twenty $U m o^{n} h o^{n}$, who had stayed at the Jardin d'Acclimatation in Paris during the previous fall. ${ }^{2}$ The distribution of such photographic compilations, which Bonaparte had been making of troupes of visiting peoples at European ethnographic exhibitions since the early 1880s, was intimately linked to his bid for entrance to the organizations and networks that comprised the developing field of anthropology. In an exchange with Dr. Paul Topinard, Secrétaire Général de la Société d'Anthropologie, concerning Bonaparte's presentation for admission to the organization and dating to January 1884 , for example, the latter indicates that he would transmit to the Secrétaire Général two of his earlier groups of pictures. Bonaparte expresses gratitude for Topinard's offer of nomination and continues, "I am going to send you this week two photographic series [...] Please accept one set for yourself and present the other to the Society in my name. They are prints from negatives that I made or had made especially for anthropological work and that I intend to publish [...]." ${ }^{3}$ As indicated here, Bonaparte both made his own pictures and 
worked with outside photographers, acting as director, in the creation of these bodies of work.

Figure 1

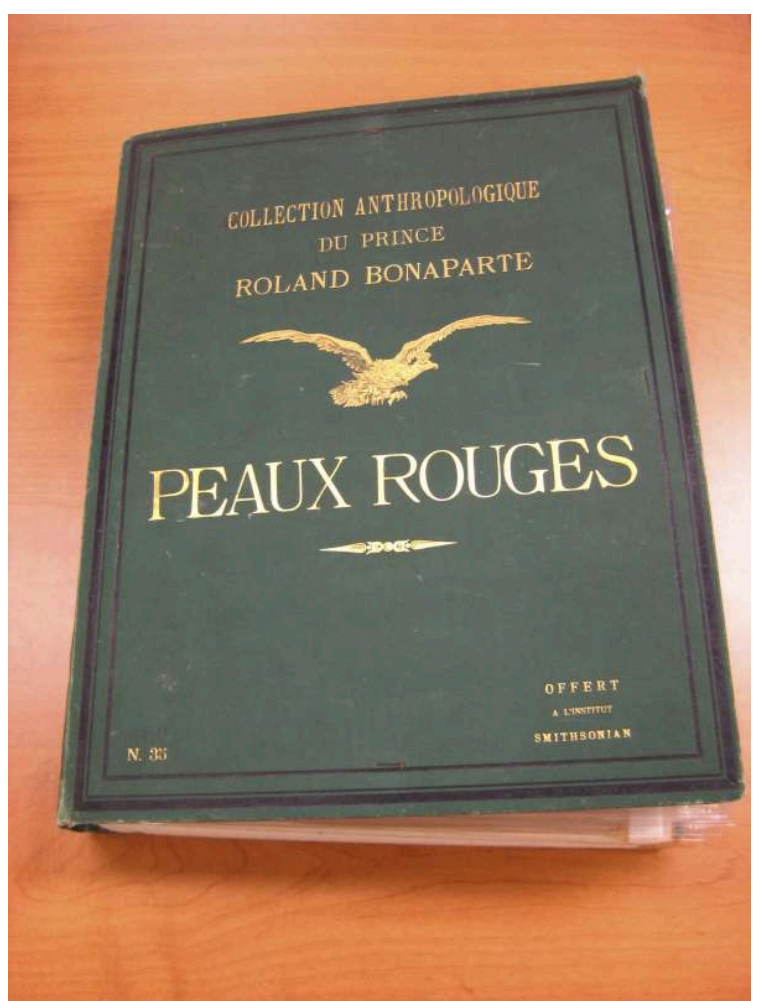

Prince Roland Bonaparte, Peaux-Rouges (1884), National Anthropological Archives, Smithsonian Institution

2 In addition to the presentation of Peaux-Rouges to sociétés savantes in Paris, Bonaparte made multiple copies and disseminated the album to organizations and individuals across national borders throughout Europe and the United States (Figure 1). ${ }^{4}$ The volumes bound for the U.S. became, like the Umonho sitters pictured within them, transatlantic travelers. The shipment of the encased albumen prints, measuring approximately $23 \times 17 \mathrm{~cm}$ apiece, reenacted materially the embodied journey of the troupe members across the ocean, retracing the Atlantic voyage back home from Paris to their reservation in Northeastern Nebraska. The singular mounted photographs were in fact, in the context of their making and initial period circulation, meant to stand in for individual bodies observed and scrutinized in the emergent study of human difference. Peaux-Rouges represents the material embodiment of a very specific type of encounter between a member of late nineteenth-century French anthropological circles-Bonaparte-and the Umo ${ }^{n} h o^{n}$ encamped at the Jardin d'Acclimatation. The compilation functioned within a larger constellation of material culture produced in the study, visualization, and imagination of race in France, grounded in sociétés savantes culture, but transmitted transnationally, decades before the professionalization of anthropology in the nation.

3 Established in 1859, the Société d'Anthropologie served as an international nexus of endeavors in physical anthropology through the end of the century. Although conceived to investigate all aspects of humanity, in reality the society focused from 
inception on what founder Doctor Paul Broca perceived as the pursuit's quantifiable aspects. Aiming to elevate the field to the empiricism of the natural sciences, Broca concentrated on the collection and comparison of anatomical data, such as crania, and the classification of races (Conklin 25; Broca). Informed by a polygenist conception of human origins and variety, Broca developed a practice to measure and make legible the alleged differences between races, theorizing about the influence of the physical on intellectual and moral capacities (Conklin 19-57). Photography operated in this context as a fundamental medium for manifesting such discourses of race visible and perceivable. Bonaparte's photographic project epitomizes the production of race-or the racial imagination, as termed by historian Amos Morris-Reich-in this intellectual milieu through the assemblage and distribution of material culture. He employed an anthropometric approach of alternating frontal and profile images throughout a group of photographic albums imaging the disparate "racial types" he encountered largely at European expositions. Peaux-Rouges represents one example from this larger series, which circulated in international anthropological networks of the period but embodied the specifically French approach of racial categorization and hierarchy.

Expanding the current scholarship on Bonaparte's Peaux-Rouges, which remains primarily grounded in the context of the volume's creation and life in these emergent anthropological cultures, this article shifts focus to the histories of the Umo ${ }^{n} h o^{n}$ sitters on the other side of the lens. Analyzing the volume through a settler colonial framework, I interpret the photographic exchange embodied in the work as a particular moment in ongoing relations between the Umon $h o^{n}$ and European, followed by Euro-American colonizers (Hoxie). Employing this approach acknowledges Indigenous nations and peoples as agents, negotiating and adapting to continuing situations of outside incursion since contact. This analysis of Peaux-Rouges positions local $U m o^{n} h o^{n}$ meanings related to these pictures as fundamental to their interpretation, as explored through collaboration with the reservation-based organization Omaha Tribal Historical Research Project (OTHRP). Examination of how these local experiences interacted with cosmopolitan cultures in Paris upon the photographs' making draws on literature figuring expanded global modernisms, such as that by historian Andreas Huyssen and art historian Ruth B. Phillips. Such an approach also traces $U m o^{n} h o^{n}$ survivance-Anishnaabe writer and critic Gerald Vizenor's term for active Indigenous presence and resistance-through the album.

5 The following analysis explores how reading the Peaux-Rouges compilation through the specificity of $U m o^{n} h o^{n}$ history, presence, and memory complicates the framework of its making in oppressive nineteenth-century frameworks of race. I argue, first, that examining the visual references to long histories of transcultural exchange within the pictures-fundamental to $U m o^{n} h o^{n}$ experience due to their central location on the midMissouri River-troubles the author's aims of racial inscription and essentialization. ${ }^{5}$ Second, I analyze the Umo ${ }^{n} h o^{n}$ as active participants in their own self-representation during the process of making these photographs and through the larger performance in the Jardin d'Acclimatation encampment, which both relied upon, and played to, preexisting conceptions of the American Indian in France. This reading interrogates the tensions between the orchestrated modes of presentation produced and the realities of enforced assimilation in the U.S., drawing on literature figuring Native agency in cultures of both performance and photography during the early reservation period (Burns; Horton, 2017; Evans \& Glass; Scarangella McNenly; Deloria). Finally, I suggest how the material life of these photographs, disseminated by Bonaparte in 1880 s 
anthropological circles but also circulating as both period prints and digitally repatriated objects in the contemporary Umo ${ }^{n} h o^{n}$ community, disrupts their framing based on presumptions of fixed, racialized identity.

\section{The Jardin d'Acclimatation, Anthropological Discourse \& Narratives of Collection}

In the late 1870s a new type of exhibition appeared in Paris at the Jardin d'Acclimatation, one of the city's zoological gardens. Peaux-Rouges resulted from this display culture and the intercultural encounters that unfolded as part of it. Although a range of animals from across the globe had been shown in the space for nearly two decades, in 1877 the venue began to showcase troupes of human visitors as well (Coutancier 34; Schneider, 2008 142; Schneider, 2011 130-144). Anthropologist Girard de Rialle describes the beginning of the phenomenon in a concurrent article in La Nature. He writes that "for some weeks," onlookers had seen "a curious caravan" of African creatures at the site-including camels, giraffes, elephants, rhinoceros, and ostrichesaccompanied by "fourteen large fellows draped in white, with bronze bodies and bizarre hair" (de Rialle, 1877a 198; Schneider, 2008 142). ${ }^{6}$ He continues by explaining that the convoy belonged to a foreign merchant who supplied such animals to European zoos by working with hunters from their native countries. However, "this time, rather than leave them [the local hunters] in Africa, he wanted to bring them to Europe, and if we are to believe hearsay, their pay won't be bad" (198). The incorporation of these fourteen chasseurs indigènes or "Nubians," as they were called in the press, proved hugely successful (Schneider, 2008 142; Schneider, 2011 132). ${ }^{7}$ Later in the same year Albert Geoffroy Saint-Hilaire, director of the space, organized a second exhibition of six Inuits from Greenland (de Rialle, 1877b). These displays quickly became the central feature of shows at the garden, and their development coincided with the growth of a similar visual culture throughout Europe and the U.S. during the same period. ${ }^{8}$ 
Figure 2

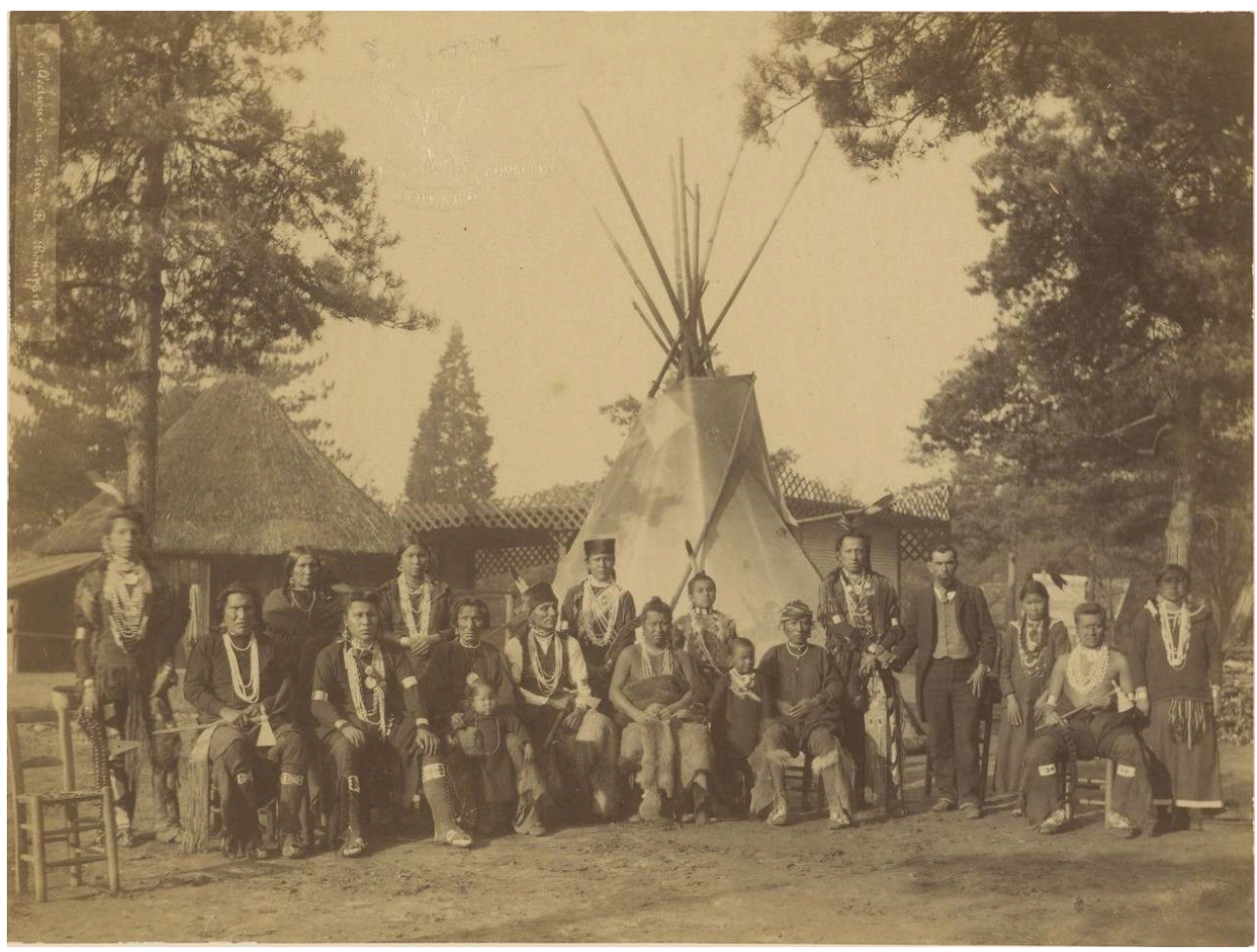

Prince Roland Bonaparte, $U \mathrm{mo}^{n} \mathrm{ho} \mathrm{O}^{n}$ at the Jardin d'Acclimatation, last photograph in Peaux-Rouges (1884), albumen print, Courtesy of Tozzer Library, Harvard University

7 The introduction of these exhibitions drastically increased attendance at the Jardin d'Acclimatation and during the closing decades of the nineteenth century, the multimedia, multisensory, and real time ethnographic performance experienced in the space attracted popular, scientific, and artistic audiences. These shows displayed visiting peoples from a single foreign locale for a period of weeks or months; they lived in dwellings on site that they often themselves constructed, which created a reality effect through fabricated material tableau (Figure 2). The Umo ${ }^{n} h o^{n}$ troupe occupied the space during November and December 1883, as attested to by the press articles written during and after their stay ("Les Peaux-rouges"; "Nos gravures"; Hamy; de Rialle, 1884; Massart; Manouvrier). They erected, and lived among, three tepees on the grounds over the course of the exhibition. ${ }^{9}$ In Bonaparte's last photograph in Peaux-Rouges, eighteen of the Umo $\mathrm{o}^{n} \mathrm{o}^{n}$ appear seated and standing before one of these dwellings. Regalia, such as the beads and bandoliers worn around numerous sitters' necks, and tomahawks poised across three of the men's laps, also added to the specificity of presentation and the sense of the foreign made somatic, material, and present. As a result of their success, period debates ensued over the intent of these displays and whether they were commercial and spectacular in nature, or held edifying, scientific value. ${ }^{10}$

8 The period scientific community engaged with this exhibition culture at the Jardin d'Acclimatation, as Director Geoffroy Saint-Hilaire worked to forge a relationship with professional circles involved in the developing arena of anthropology from the inception of the shows. He sent personalized letters, invitations, and tickets to members of the Société d'Anthropologie, inviting them to visit the exhibitions and interface with the performers in residence at the garden through the late $1880 \mathrm{~s} .{ }^{11}$ One 
such letter, sent from Geoffroy Saint-Hilaire to Topinard on January 1881 seeks to aid in the organization of an excursion and reads,

I am entirely at your service to facilitate the examination of our Eskimos by the Société d'anthropologie's committee. Please tell me the number of people [...] [and] day chosen for the visit [...] I hasten to get you the necessary authorizations to enter into the garden and the enclosure reserved for the Eskimos. ${ }^{12}$

9 French anthropological inquiry of the era relied on the collection and comparison of anatomical material to demonstrate the polygenist conception of racial hierarchy espoused by Broca (Conklin 19-57; Dias, 1998 36-52; Dias, 1997 33-47). Brocan anthropologists occupied a place as international leaders in the measurement and comparison of skulls as well as the classification of "races." Members of the discipline in France undertook the study of visiting peoples, rather than completing periods of ethnographic immersion or fieldwork (Conklin 22-29). Based on an a priori conception of human difference, this amassing of material aimed to demonstrate the allegedly innate distinctions and hierarchy between extra-European groups, such as their "psychic capacities" (Dias, 1998 37; Conklin 26).

The Jardin d'Acclimatation therefore appeared to this community as an ideal venue for the collection of supposed data. As soon as the exhibitions appeared, the Société d'Anthropologie formed a special committee under the direction of Broca, "charged with carefully examining the natives camped at the gates of Paris," as described by de Rialle (de Rialle, 1877a 198). Evidence of the encounters that ensued fills the pages of period publications such as the Bulletin de la Société d'Anthropologie and La Nature. The "data" collected during these interactions included bodily measurements, drawings, photographs, and the identification of skin, hair, and eye color. Broca established uniform methods, along with specifically designated instruments, for assembling such material, indicating that his instructions applied not only to travelers, but observateurs sédentaires, working in such exhibition spaces (Broca 5, 20-100). Members of the Société d'Anthropologie often compensated visiting troupe members, such as the Umon ${ }^{n} o^{n}$, to secure participation and amass these specimens, which eventually joined the society's collections and served to establish or support preexisting racial theories (Manouvrier 723). 


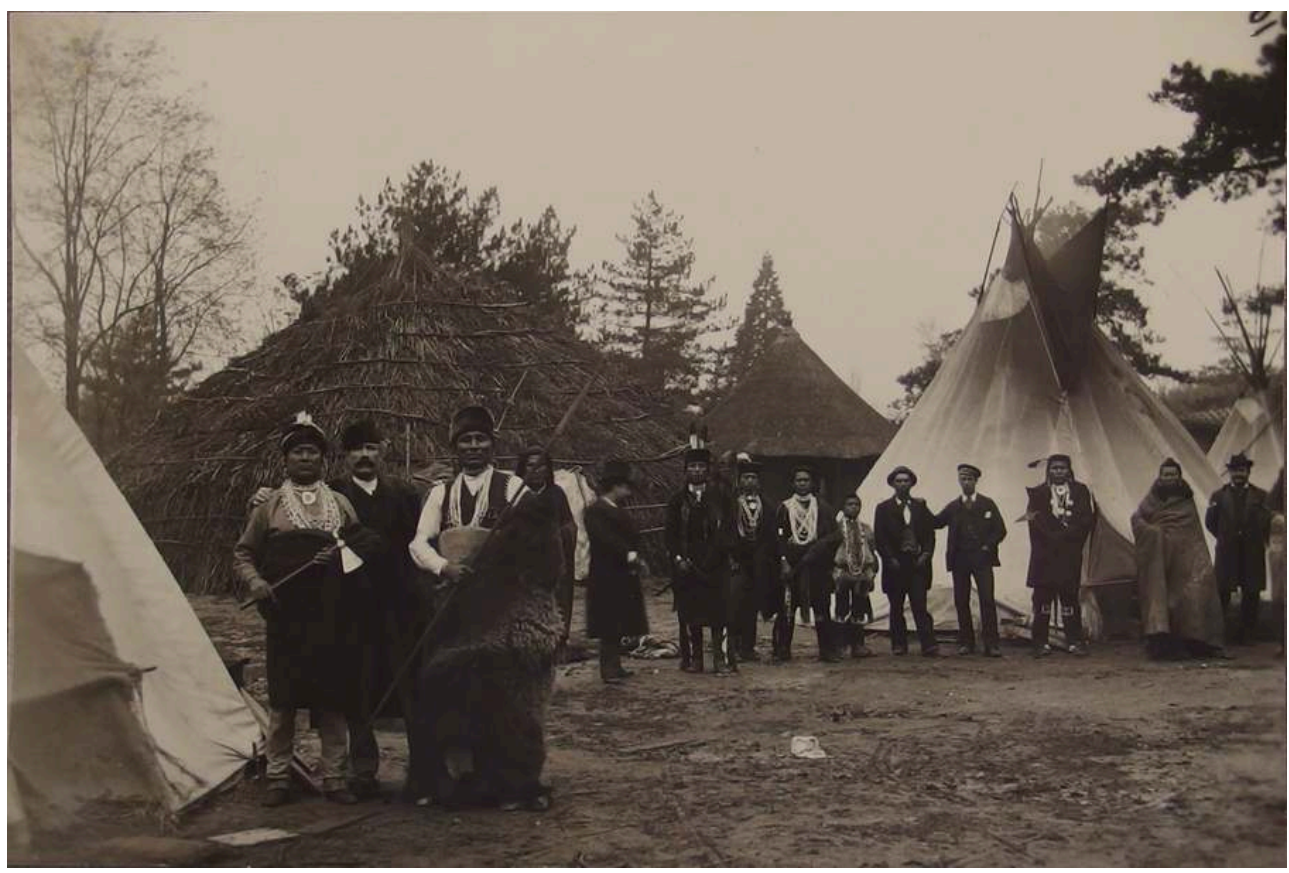

Prince Roland Bonaparte, Outtake from Peaux-Rouges (1884), Maquette (Later print), Musée du Quai Branly - Jacques Chirac, Paris, Dist. RMN - Grand Palais / Art Resource, NY

11 Bonaparte epitomizes this period milieu, for he utilized the simulated geography of the French ethnographic exhibition as the terrain in which to undertake his "fieldwork" and photographic project. ${ }^{13}$ Bonaparte trained at the École d'Anthropologie, a private school established by Broca in 1876 for dispensing disciplinary knowledge, and became a member of the Société d'Anthropologie early in 1884, as indicated by his exchange with Topinard discussed at the outset of this article (Cordier 4-13). A photograph of the $U m 0^{n} h o^{n}$ encampment taken during Bonaparte's visit over the course of the 1883 show visually embodies his methodology (Figure 3). This picture is not included in the final version of the album but rather in what appears to be the maquette for the project, along with four other "outtakes" made in the space of the garden, and a map, all of which did not make it into the ultimate iteration of the compilation. ${ }^{14}$ Wearing a top hat and overcoat and blurred due to movement during the exposure time, Bonaparte stands here "in the field" of the Jardin d'Acclimatation talking to the $U m o^{n} h o^{n}$ at center, as if directing a picture ( they extend in various standing poses facing the camera in a row to the right). In the left foreground, another visiting Frenchman, most likely from the anthropological community, stands with his arms around two members of the troupe-Inshta-Iabi (Bright Eye) at left and Montchou-Naji (Standing Bear) at rightwho hold up a tomahawk and spear respectively. The image renders some of the complexity of the cross-cultural encounters that took place in these exposition spaces, in which disparate cultural groups came together, interacted, and reckoned with each other in a process of two-way exchange despite unequal power relations (Pratt 1-12). As opposed to the carefully controlled sequence of pictures that resulted from these exchanges in the final volumes, such outtakes demonstrate the performative orchestration that went into staging the progression. 
Figure 4
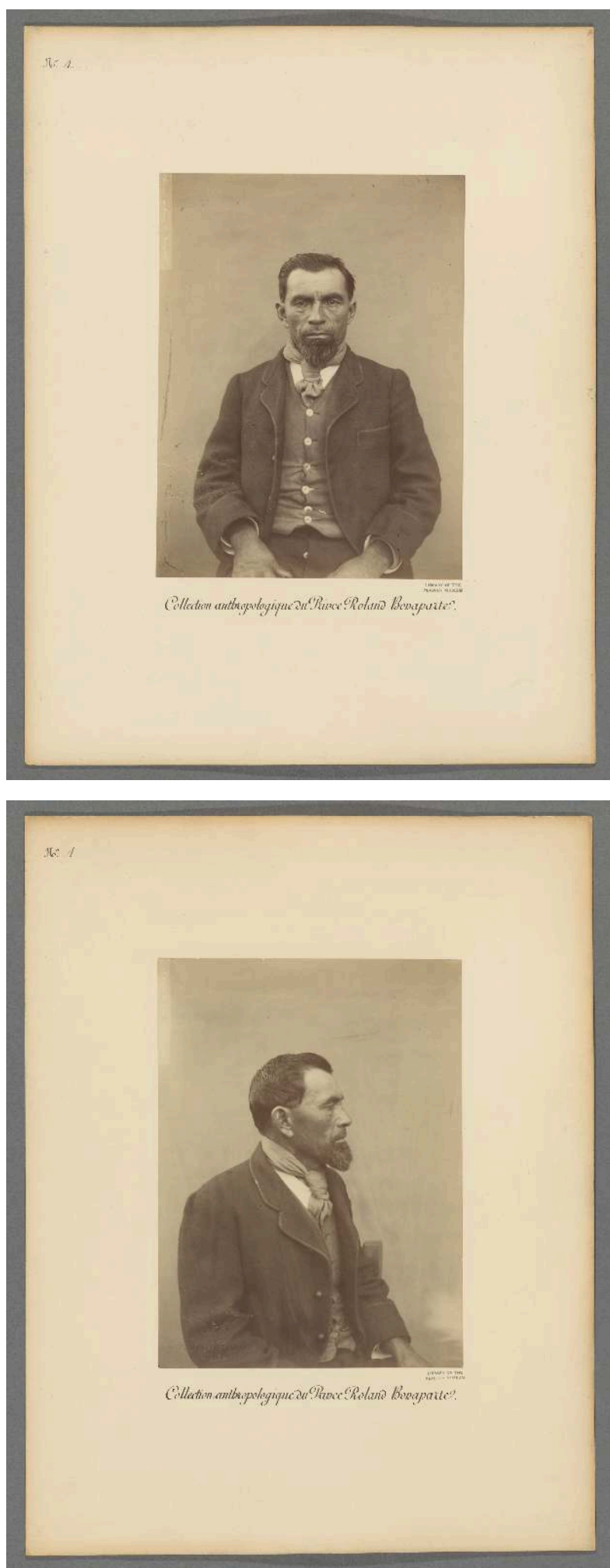

Prince Roland Bonaparte, John Pilcher, Peaux-Rouges (1884), albumen prints, Courtesy of Tozzer Library, Harvard University

12 From these encounters with the Umo ${ }^{n} h o^{n}$ at the Jardin d'Acclimatation, Bonaparte produced Peaux-Rouges, in which his methodical ordering of sitters into frontal and profile photographs directly relates to Broca's instructions for the collection and 
creation of anthropological materials (Figure 4). The final version of the compilation contains an opening booklet after the introductory gift letter that briefly describes the $U m 0^{n} h o^{n}$ and their territory, followed by a numbered list of the seventeen adults shown. This list contains Bonaparte's-or whomever he was working with at the garden'sinterpretation of each sitter's name, including the Native version and its EuroAmerican translation (in English or French), along with other social descriptors. ${ }^{15}$ As the viewer opens the large case and progresses through the pictures in the order dictated by the enclosed textual pamphlet, they view first the straight-on image, such as that of John Pilcher-the first sitter in the album-and then progress, in flipping it over, to the profile.

Broca advocated for the use and acquisition of photographs in anthropological collections, along with casts from living models, drawings, and anatomical materials. For photographs in particular Broca stipulates that the exposed face should always be frontally represented, or alternatively, the head should be exactly in profile, as he asserts, "the other points of view have no utility" (Broca 6). In standing portraits, he maintains that the subject should be upright, facing frontally, and appear as nude as possible; however he also recognizes that the characteristic accoutrements of the group have their importance (Broca 6). Brocan anthropometric techniques of imaging the human subject would subsequently have a long life, as Alphonse Bertillon-whose father Louis-Adolphe Bertillon taught demography at Broca's École d'Anthropologieestablished a criminal identification system based on them (Conklin 47; Barthe 66; Sekula 18-40). Alphonse Bertillon's photographic method of classification, first adopted by the Paris police force in 1883, led to the creation of an archive using cards that stored criminal information (Sekula 18-40; Morris-Reich 36-41). Based on rigorous uniformity, the system catalogued the socially deviant with the same modes of imaging used to visualize conceptions of racial difference, as developed by Broca. The approach in the methodically ordered views in Peaux-Rouges, and the larger principles of organization in the work, correspond with and make material the aims of legibility and classification fundamental to nineteenth-century French anthropology.

Bonaparte produced multiple copies of Peaux-Rouges for international distribution and although the color of the volumes' framing cases varies-from green to purple, gray or red-these multiple sets consistently employ the same gold text (Figure 1). The gleaming letters announce the title in the largest script in all capitals towards the center, and at the top the name of the privately funded, Collection Anthropologique $d u$ Prince Roland Bonaparte, indicates the origin and conceptual author of the photographic enterprise. The figure of the French Imperial eagle, with wings spread in flight and wearing a crown, appears between these two textual components. In the lower right corner of the cover appears the institution to which the book was offered, in this case the Smithsonian Institution in Washington, D.C, and on the opposite (left) side we see a number in the sequence of Bonaparte's distribution, here thirty-five. ${ }^{16}$ Ninety-three represents the highest of these numbered volumes I have encountered, giving a sense of how many of these tomes there were-and possibly still are-in circulation. ${ }^{17}$ Disseminated in developing anthropological networks of the period, these photographs participated in concretizing ways of seeing race. 


\section{Unfixing the Frame: Visualizing Histories of Intercultural Contact \& Exchange in Peaux-Rouges}

15 The attempt to fix the pictured sitters in the project based on essentialized notions of racial identity is complicated, however, through references to long histories of intercultural contact and exchange, characteristic of the history of the Umo $\mathrm{n}^{n} \mathrm{o}^{n}$ nation and apparent in the photographs. Peaux-Rouges, the term used in France to describe all American Indians during this period, posits a monolithic Native identity, with the pictured sitters offered as samples of the "race". This generalized terminology and oppressive mode of presentation fails to acknowledge tribal differences, and the distinct beliefs, practices, and histories of diverse Indigenous groups. Furthermore, the construct does not account for the vast spectrum of experience within such cultures, as demonstrated by the range of individuals shown in the album, commencing with adult men and concluding with the women and children in the troupe. Yet, visual and material aspects of these pictures themselves-and their relationship to recorded $U m o^{n} h o^{n}$ history and experience-unfix the framing discourses and approach of Bonaparte's project.

16 According to tribal oral traditions, the Umon $h o^{n}$ originated in the Ohio River Valley and then migrated west and north along the Missouri River beginning around 1600, relocating numerous times before settling in present-day Northeastern Nebraska by the late 1700s (Hastings and Coffey 90-109). Due to their location on the Missouri River, the $U m o^{n} h o^{n}$ have had a long history of cross-cultural contact-with Europeans, later Euro-Americans, and other Native nations-through situations of exchange such as trade networks. In the eighteenth and first half of the nineteenth centuries, these interactions were particularly tied to the fur trade economy, still influenced by the French even after the end of their colonial presence in the region in 1763 (Thorne; Gitlin). With the creation of the Omaha Reservation in 1854, followed by a period of further treaties, exchange with Euro-American culture continued and intensified through the era of government instated assimilation (Hastings and Coffey 323-340). Elements of the Umon $\mathrm{Ho}^{n}$ negotiation of these various forms of contact appear in the Bonaparte photographs, and the images as well as the archival materials associated with them indicate the troupe members' agency during the exchanges that the making of these pictures represented.

17 The first sitter in the album, John Pilcher, draws attention to this long record of intercultural contact, as well as the more recent work of assimilation, through his personal history, as well as his representation in the book (Figure 4). Bonaparte, or whoever recorded the individuals at the Jardin d'Acclimatation in the making of the volume, misspelled Pilcher's name, calling him "John Pelcher" in the list of included sitters that precedes the photographs (Hastings and Coffey 730-736). These errors in recording names are common in Bonaparte's projects in that he and the other members of French anthropological circles most likely gathered such details during oral exchanges on the grounds of the public exposition space. Pilcher arranged the details of the Umon $h o^{n}$ visit to Paris and was the son of a famous Euro-American trader, Joshua Pilcher-Director of the Missouri Fur Company from 1822 through the late 1830s-and an $U m o^{n} h o^{n}$ mother named Poporine (Hastings and Coffey 730-731, 182, 190; Sunder). The two had married in 1833, however Poporine died of cholera around the time of childbirth, leaving Joshua Pilcher with the baby, who had no concern for caring for 
him. The Umo ${ }^{n} h o^{n}$ leader Big Elk took responsibility for the child John, and he was raised among the Native community, but he kept his father's name of Pilcher (Hastings and Coffey 182, 190; Sunder).

Although the sitter's father Joshua Pilcher was Euro-American, French traders also married $U m o^{n} h o^{n}$ women, and a long history of interaction and exchange exists between the two cultures. The first contact the Umon $h o^{n}$ had with Europeans was most likely through French traders and missionaries journeying down from Canada around the mid seventeenth century (Thorne; Hastings and Coffey 27, 98). French travelers and cartographers were also the first Europeans to note the location of the Umon $h o^{n}$, referred to by these outsiders as the Mahas, in their records and on their maps (Hastings and Coffey 98-102; Shea). These traders brought with them diseases such as smallpox, and most likely first introduced the Native populations of the upper Missouri to alcohol. Along with importing these influences, European goods, and information, many of them also remained and lived among the Umon $h 0^{n}$, marrying women in the community.$^{18}$ Lewis and Clark's Corps of Discovery (1803-1806), for example, employed two Umo ${ }^{n} o^{n}$ French guides-Pierre Cruzatte and François La Biche-who brought multiple languages and knowledge of the Missouri River and region to the expedition (Hastings and Coffey 167).

This longstanding relationship between the Umon $\mathrm{ho}^{n}$ and the French helps illuminate the recruitment of the troupe that traveled to Paris in the fall of 1883. The French had long traversed this portion of the Missouri River, which by the late nineteenth century contained heavy steamboat traffic..$^{19}$ The agent who sought a group of American Indians for the Jardin d'Acclimatation exhibition might have had specific ties to the Umo ${ }^{n} h o^{n}$ and Pilcher, or stopped at the community and formed a relationship with the latter. Pilcher's history, as well as his willingness to organize the exhibition, suggests his having ties to both the white and Native worlds.

These elements of Pilcher's history appear in his presentation in the album. As Bonaparte writes in his description of this first sitter of the compilation, he is "conductor of the caravan; forty-two years old; his father is American and his mother is Indian; he is married and has eight children" (Bonaparte 1). This text not only signals Pilcher's role as organizer and leader of the Umo $\mathrm{H}^{n} \mathrm{o}^{n}$ visit to the Jardin d'Acclimatation but also disrupts the notion of fixed racial categories on which Bonaparte relies. By showing a subject with an Anglo as well as a Native parent, Bonaparte suggests this much longer history of intermarriage and intercultural entanglement and complicates the idea of pure examples of an American Indian "race." This tension of a false construct of identity, imposed upon the sitters, also appears in the image itself. For Pilcher sits within the contained frame of the anthropological image, among the pages of the Peaux-Rouges album-surrounded by Bonaparte's identifying insignia-yet wearing European style dress. He dons a tie, buttoned-up vest, and collared jacket and also sports a short haircut and cleanly shaped beard. These Euro-American markers of appearance call into question the encasing confines of the anthropometric format of the image, which attempts to pin down a single, inherent racial identity. Beginning the book with Pilcher instead signals larger histories of contact, exchange, and ongoing flux. 
Figure 5
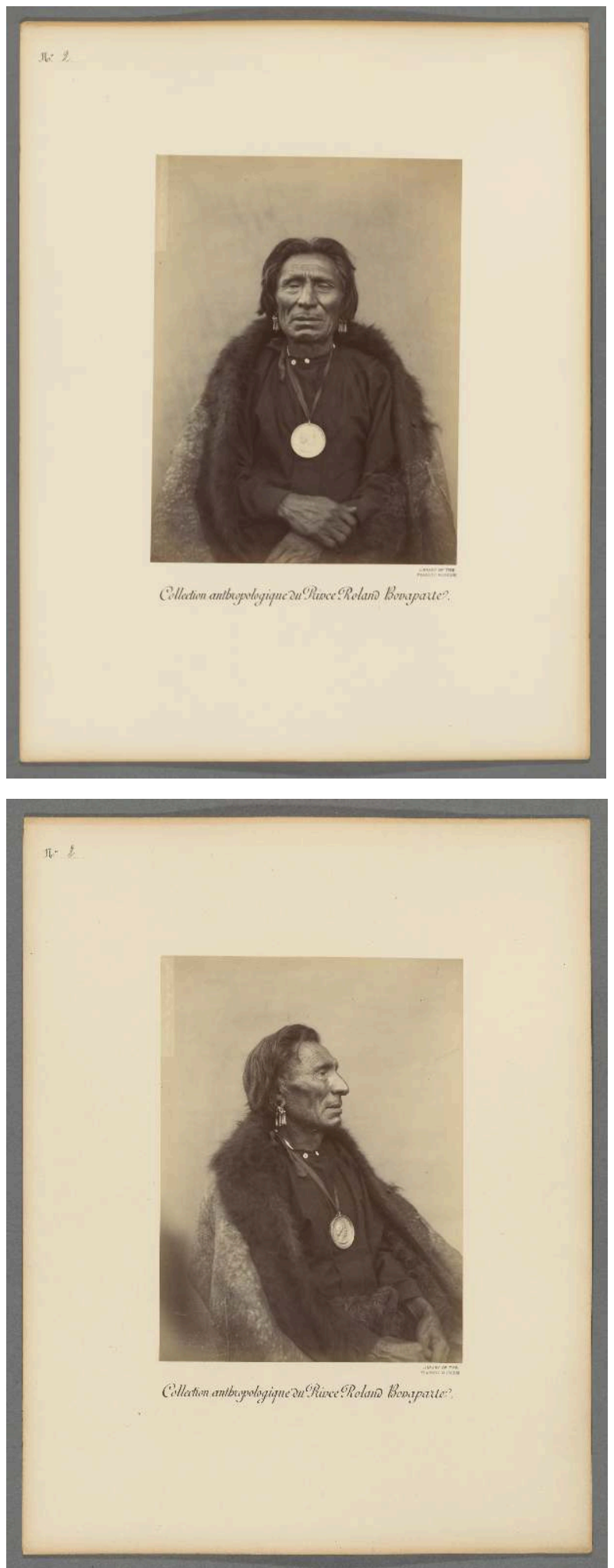

Prince Roland Bonaparte, Shoudé-Nasi or Yellow Smoke, Peaux-Rouges (1884), albumen prints, Courtesy of Tozzer Library, Harvard University

21 The representation of the second sitter in the sequence, Shoudé-Nasi (Yellow Smoke), also suggests a history of cross-cultural exchange, as well as diplomatic interaction (Figure 5). He sits in both frontal and profile views with a buffalo hide draped around 
his shoulders, and a large gleaming peace medal hangs from his neck. These material symbols of tribal status and negotiation commonly feature in photographic delegation portraiture made of visiting Native diplomats in Washington, D.C. throughout the $1860 \mathrm{~s}$ and ' 70 s. $^{20}$ The peace medal, awarded to tribal leaders along with other gifts by the U.S. government upon events such as the signing of treaties, historically signified good relations between the two parties. This convention of gift giving followed the British and French practice of granting silver medals to Native dignitaries, and all U.S. presidents through the 1880s gave the objects to important American Indian figures upon diplomatic occasions. Over the course of the nineteenth-century, however, both the iconography on the medals, and the circumstances of their giving, reflected the increasingly imbalanced power dynamics of the settler colonial relationship between the U.S. and Native peoples (Lubbers; Harjo). Shoudé-Nasi was the last member of the Council of Seven Chiefs to sign the 1854 treaty that established the Omaha Reservation (Ridington and Hastings 61; Hastings and Coffey 332, 336). The medal that appears so prominently in these paired photographic portraits might have been given to mark this particular occasion.

\section{Performing Indigeneity in Paris / Assimilation at Home}

The U.S. government issued another round of changes related to the $U m o^{n} h o^{n}$ s land and lifeways just before the troupe's 1883 passage to Paris. Shoudé-Nasi who, as Bonaparte notes, was seventy-five years old during the group's trip witnessed and negotiated all of these transformations and dislocations during the post-reservation formation era. In 1882 Congress issued the Omaha Severalty Act, due largely to the efforts of Alice C. Fletcher's lobbying, which provided that communally-held reservation land be broken into individual family plots (Ridington and Hastings 9). The following year, in 1883 while the $U m o^{n} h o^{n}$ traveled to Paris, Fletcher worked as special agent to carry out the allotment, with Francis La Flesche serving as interpreter ${ }^{21}$ This legislation served as a central element of assimilation efforts, the breaking up of collective tribal land meant to destroy Indigenous lifeways and replicate the Euro-American family structure, fixing individuals and family groups to assigned geographical parcels and enforcing agricultural self-sufficiency. The act of 1882 not only sought to accelerate the process of allotment, which had begun in the wake of the 1854 treaty, but also provided for the sale of 50,000 acres of "leftover," or unassigned, reservation land, opening this area to white settlement and further eroding Umon $\mathrm{U}^{n}$ sovereignty (Hastings and Coffey 436). Fletcher's work on the project was instrumental in, and served as the model for, the later General Allotment, or Dawes Act of 1887, which provided allotment for most Native territory and similarly entailed the sale of "surplus" land holdings.

A disconnect or resistance, therefore, characterizes the fact that the $U m o^{n} h o^{n}$, who served as the test case for one of the central U.S. assimilation policies with the 1882 Severalty Act, traveled to Paris to showcase their Indigenous identity just as allotment was taking place. A corresponding element of performance characterizes the photographs, in their visual orchestration informed by French imaginaries that belied the rapidly changing realities of reservation life. This element of the display is also noted in period textual material surrounding the troupe's visit. As Léonce Manouvrier, member of the Société d'Anthropologie described at a society meeting after numerous visits to the $U m o^{n} h o^{n}$ at the Jardin d'Acclimatation, "these children of warriors and 
hunters" were already "half civilized" and had become farmers (306). Manouvrier detailed,

Many knew how to read and write and one of the women could fluently speak English. But they were true Redskin Indians nonetheless [...] and the administration that brought them to Paris took care to dress them in their national costumes [...] In their country, in fact, it seems they liked to dress in European clothing. But in Paris, it was in their own interest to appear as Indian as possible [...] they understood very well that they were there to show themselves to the Parisians (Manouvrier 306).

Manouvrier's quotation conveys awareness of the self-consciousness that characterized the Umo ${ }^{n} h o^{n}$ 's constructed and active cultural enactment in Paris. The account also suggests ways that travel and performance abroad might have served as a means by which the $U m 0^{n} h o^{n}$ navigated changing and oppressive circumstances under assimilation legislation that sought to confine individuals and regulate the embodied expression of Indigenous identity. Numerous scholars have explored the opportunities that participation in forms of performance provided Native people, and especially those from Northern Plains communities, from the 1880s through the turn of the century (Burns 16-18, 25-55; Scarangella McNenly 3-20; Deloria 69; Moses 1-9). Along with compensation and mobility, such a role might allow for engagement in activities and expression actively suppressed through legislation at home.

Figure 6

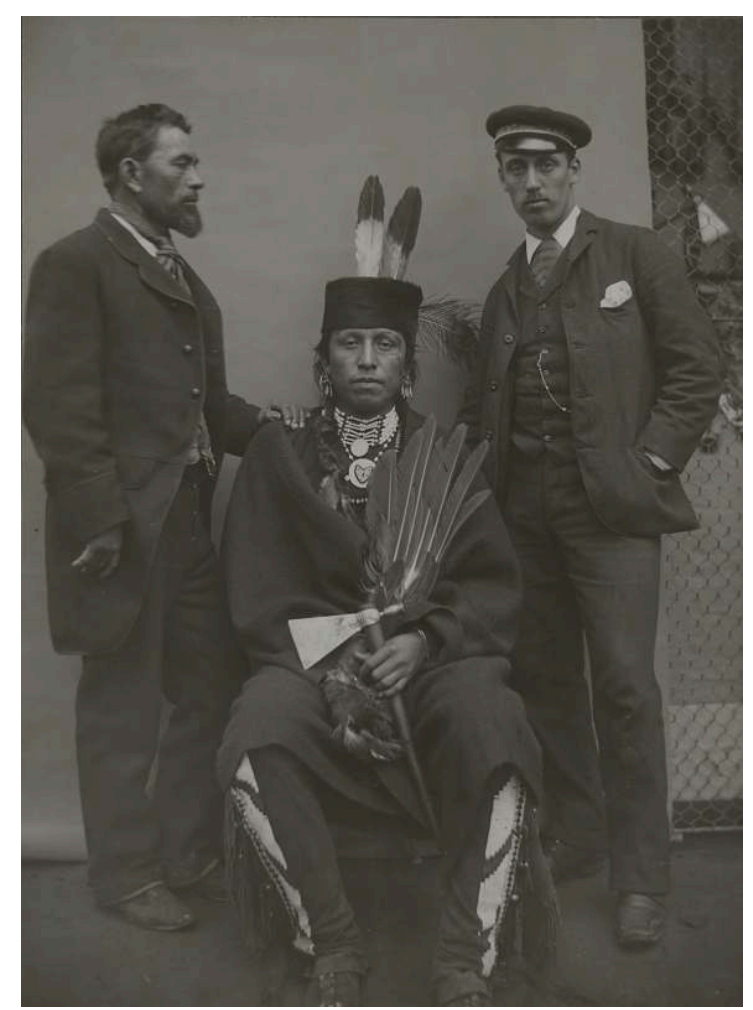

Prince Roland Bonaparte, Outtake from Peaux-Rouges (1884) Maquette (Later print), Musée du Quai Branly - Jacques Chirac, Paris, Dist. RMN - Grand Palais / Art Resource, NY

The performative aspect of these pictures, and the processes involved in their staging, appears particularly clearly in one of the outtakes-not included in the final PeauxRouges album-of Iba Hambi (Homme Connu) seated with John Pilcher and a keeper in the garden standing on either side (Figure 6). Pilcher stands on the viewer's left and 
rests his hand on Iba Hambi's shoulder, while the keeper, on our right, looks assertively into the camera, his hat tilted on his head. The staged quality of these three figures inside the frame-posing a hand statically at left, tilting shoulders dandily at right, and holding a range of objects at center-captures the self-display within the garden; the choreographed posing of characters before the lens. A cinematic element characterizes the image, in which Iba Hambi clutches a group of items like props, including a pipe tomahawk and an eagle feather fan, only one of which he displays (the fan) in the ultimate Peaux-Rouges volume (Figure 7). The white sheet that forms Bonaparte's studio backdrop also slips inside the edge of the camera frame at right in the outtake, revealing the chain link fence in the garden that comprised the enclosure in which the $U m o^{n} h o^{n}$ stayed. This slippage points to the constructed nature of the scenes staged before the makeshift background, and in the Jardin d'Acclimatation more largely. My reading here draws on the work of visual anthropologists Elizabeth Edwards and Deborah Poole, who examine this "visual excess" and "temporal contingency" recorded in abundance in historical anthropological photographs, despite efforts of rigorous control by producers (Edwards; Poole). Interpreting this "excess" as visual embodiment of a two-way encounter acknowledges the disconnect between the discourses of race in which these pictures were made and the exchange that took place during the actual picture-making process, here suggested by the outtakes that fissure the final sequence in Peaux-Rouges (Evans \& Glass 10).

\section{Figure 7}

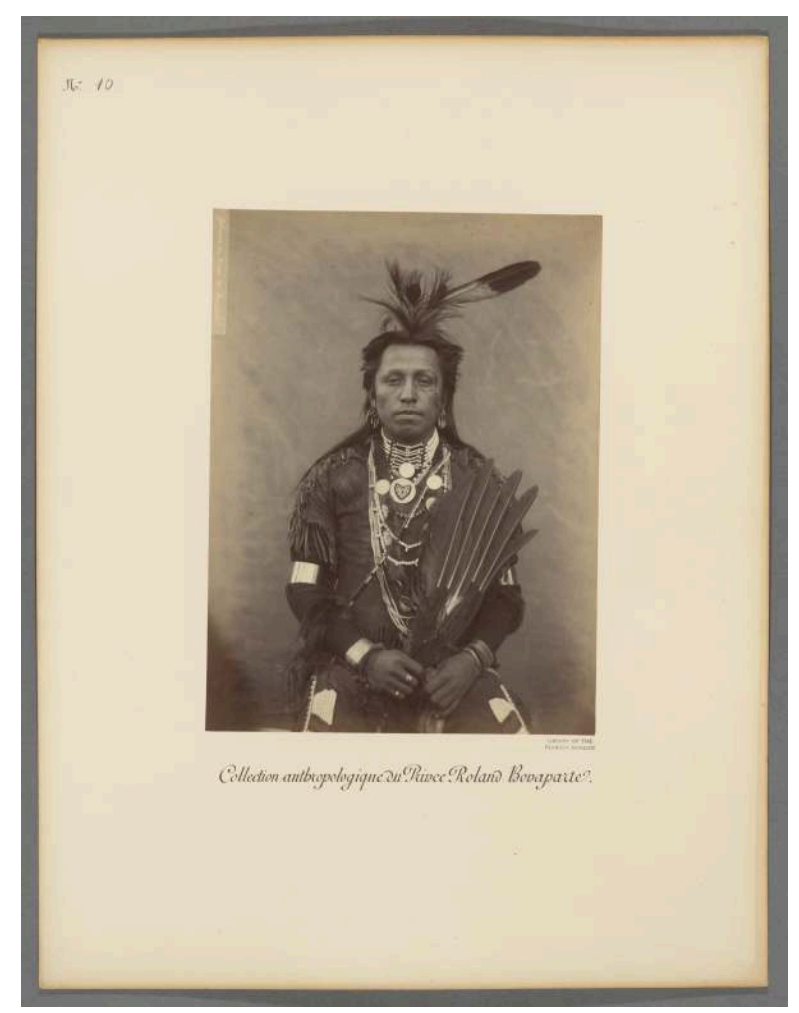




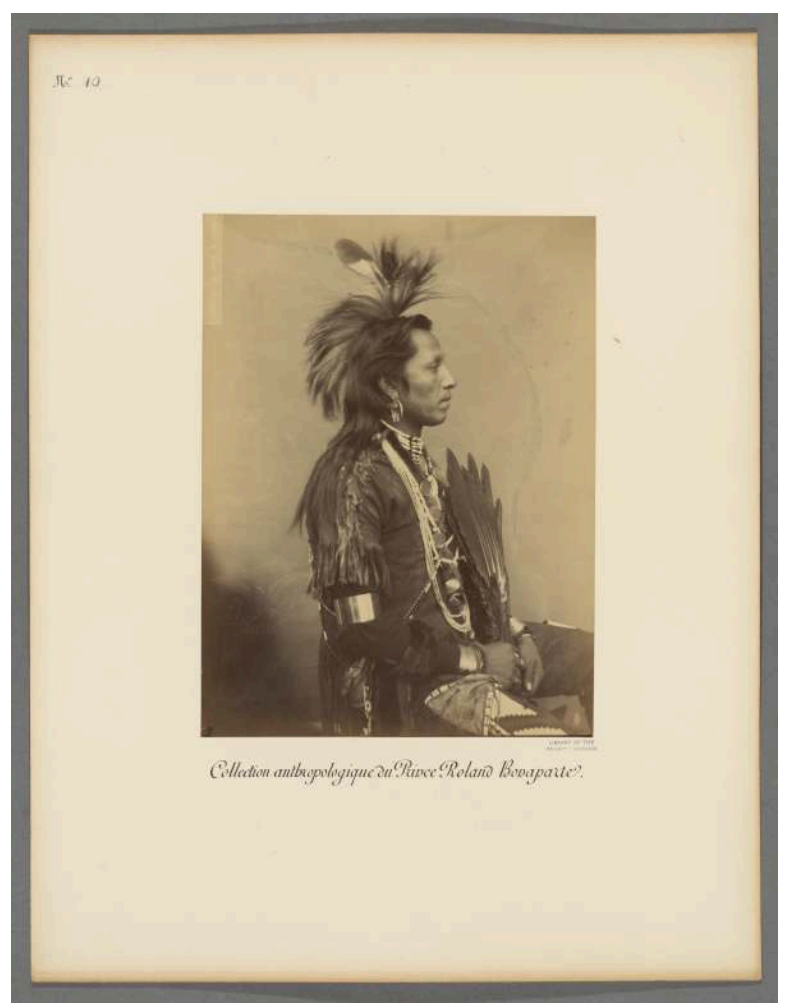

Prince Roland Bonaparte, Iba Hambi or Homme Connu, Peaux-Rouges (1884), albumen prints, Courtesy of Tozzer Library, Harvard University

This performance at the Jardin d'Acclimatation and the Bonaparte photographs that resulted drew upon earlier modes of representing the American Indian, by this time long circulating in the Atlantic World. Troupes of Native peoples, as well as other depictions of Indigenous North Americans, had appeared in France since the sixteenth century with the nation's earliest explorations of the Atlantic coast. In the seventeenth and eighteenth centuries such delegation visits related heavily to cultures of diplomacy, as European nations vied for power in North America in conflicts that relied on Native alliances (Harjo). The presence of $U m o^{n} h o^{n}$ at the Jardin d'Acclimatation might conjure colonial nostalgia for this history of New France. Bonaparte himself had a specific imperial relationship with North America. His great uncle Napoleon I sold the vast Louisiana Territory to the U.S. in 1803, after acquiring it back from Spain three years prior in hopes of reviving France's two-century long dominance in the region that came to an end in 1763. His interest and approach in Peaux-Rouges, although rooted in historically specific cultures of imagining race, relates to longer textual and visual modes of depicting exchange with Northern Plains Indigenous nations during the colonial period.

In the nineteenth century specifically, the visual culture of Indigenous live performance gained increasing force with the emergence of showmen who commercialized the ethnographic display, coinciding with the burgeoning field of anthropology. American artist and entrepreneur George Catlin epitomizes the economically motivated ethnographic enterprise that developed during this period. $\mathrm{He}$ made numerous trips up the Missouri River in the 1830s, producing painted portraits and scenes of Native life in the region, which comprised his Indian Gallery. In 1845 he brought the collection to Paris with a group of Iowa performers, soon to be replaced by a troupe of Ojibwa (Catlin; Beetem; Horton, 2016 134; Horton, 2017 157-165; Burns 21, 
35). Catlin's project typifies the salvage and archival impulse of the period-created as he emphasized to preserve allegedly disappearing lifeways-and captured the attention of Romantic artists and writers in France, such as Eugène Delacroix, Charles Baudelaire, and George Sand (Beetem). The Umon $h o^{n}$ performance at the Jardin d'Acclimatation, featuring an abundance of clothing and objects not worn at home, as Manouvrier notes, echoes Catlin's detailed focus on Plains regalia as means of record (Manouvrier 306). The memory of this earlier visual display also intersected with period literary culture, such as the novels of James Fenimore Cooper, especially his Leatherstocking Tales, which enjoyed popularity in France beginning in the 1820s (Thorp 525). As de Rialle writes in La Nature about the Umo ${ }^{n} h o^{n}$ encampment, "There are there ten men, ten vigorous fellows of high standing [...] of the type characteristic of their race, which naturally represent the savage red warriors in the novels of Cooper and Mayne Reid [...]." (de Rialle, 1884 6). ${ }^{22}$ De Rialle here describes the figures seen as living embodiments of previous representations in text and image.

While numerous viewers interpreted the performative display of the $U m 0^{n} h o^{n}$ at the Jardin d'Acclimatation filtered through the matrix of previous art, visual, and literary culture, others noted the changes being wrought on their culture. Ernest Théodore Hamy, curator at the Musée d'ethnographie du Trocadéro, bemoaned these alterations with language characterized by primitivist wistfulness. In an article he authored in Science et Nature in 1883 he recounts a history of the different Native American groups brought to France and describes the current troupe at the garden. In reference to these performers, he expresses nostalgia for their $U m o^{n} h o^{n}$ ancestors and a longing for some moment of imagined, pre-contact cultural purity. In contrast to the past, Hamy indicates that the contemporary $U m o^{n} h o^{n}$ have become sedentary, gained agricultural instruments from the U.S. government, and now cultivate crops. He posits that due to this alteration in their lifeways, the Umon $h o^{n}$ are "overrun with portliness," in comparison to the romanticized "svelteness and elegance of forms that so deeply struck our predecessors in admiring the Iowas [that visited with Catlin] in 1845" (3).

In addition to this supposed "heaviness" and "fattening" remarked upon by Hamy, apart from which he believes the $U m o^{n} h^{n}$ are nevertheless "fine specimens of their race," he asserts that the objects the troupe possesses are just mediocre. He maintains that the "special industries of their ancestors have been profoundly altered in their hands" and laments the perceived decline in their quality due to the introduction of industrial materials (4). Of this alleged decay he writes,

The tents are in canvas or cotton, in place of buffalo skin [...] The porcupine spike embroidery that decorated their moccasins, leggings and blouses has been replaced with polychrome European beads [...] and their hairdressing has taken on a quasiEuropean appearance. One of the warriors wears, for example, a sort of wool turban wrapped around his head like that of certain trappers (Hamy 4).

With these discourses, Hamy fixes "uncorrupted" Umon $h o^{n}$ culture in a conjured premodern ethnographic past, before the introduction of manufactured goods or outsiders, rather than recognizing its long historical change and accommodation through situations of contact. In his romanticism of this imagined past, he fails to identify any of the causes for these morphing $U m o^{n} h o^{n}$ lifeways and modes of material culture production, such as assimilation, the eradication of buffalo on the plains by the 1870s, and long histories of trade and exchange. Instead, he laments exactly the process being enforced by U.S. Indian policy. 
Hamy's nostalgia for an untainted past fails to acknowledge these processes of enforced change and also lacks awareness of the way that the Umo ${ }^{n} h o^{n}$ negotiated this experience of transformation, and had historically, to adapt outside influences to their own cultural needs and survival. His description of the troupe's material culture is rife with suggestion of the over two centuries of cross-cultural exchange-with Europeans and later Euro-Americans-that characterized the Umo ${ }^{n} h o^{n}$ s central location along the Missouri River. He mentions "polychrome European beads" and a wool turban in the manner of "certain trappers," but these were not new phenomena. From the beginning of contact with Europeans the Umo ${ }^{n} h o^{n}$ integrated materials introduced through traders into their clothing and regalia. As Fletcher and La Flesche write, "From the first the native industries were affected by the advent of the traders, who introduced articles of white manufacture" (Fletcher and La Flesche 612). They describe the integration of metal tools, colorful glass beads, and cloth purchased by the yard. The objects and clothing donned by the sitters in Peaux-Rouges, such as the wool blanket, metal pipe tomahawk, and beads that adorn Iba Hambi, all embody these histories of contact (Figure 6-7).

Figure 8

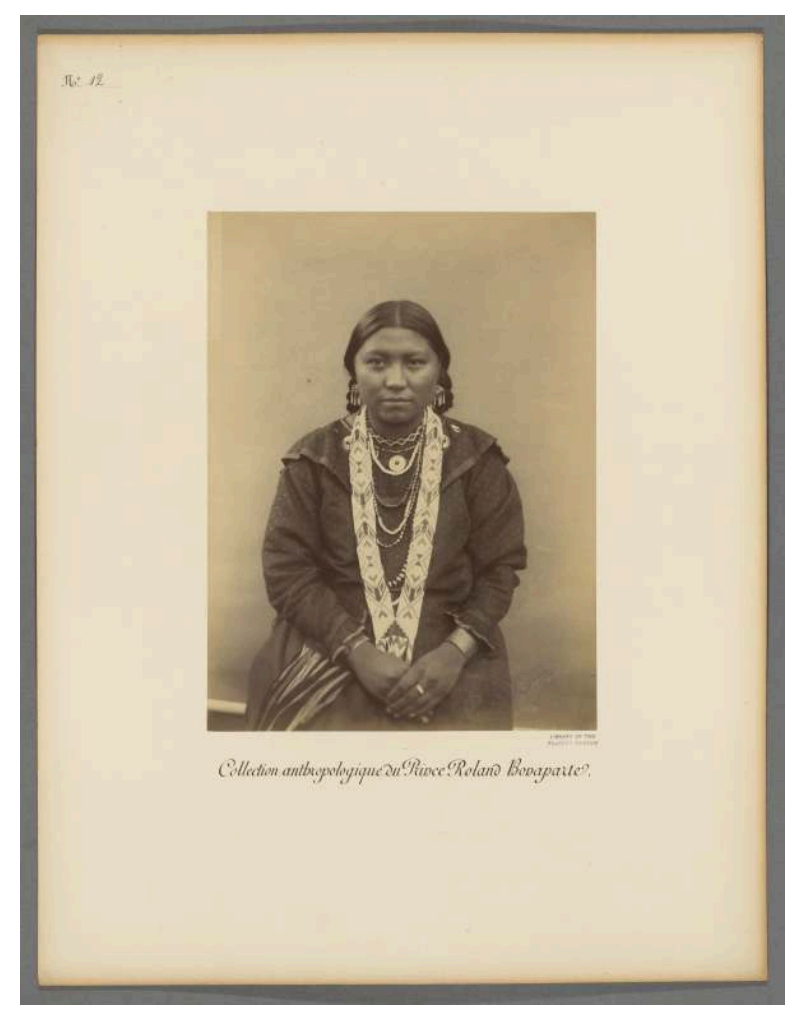




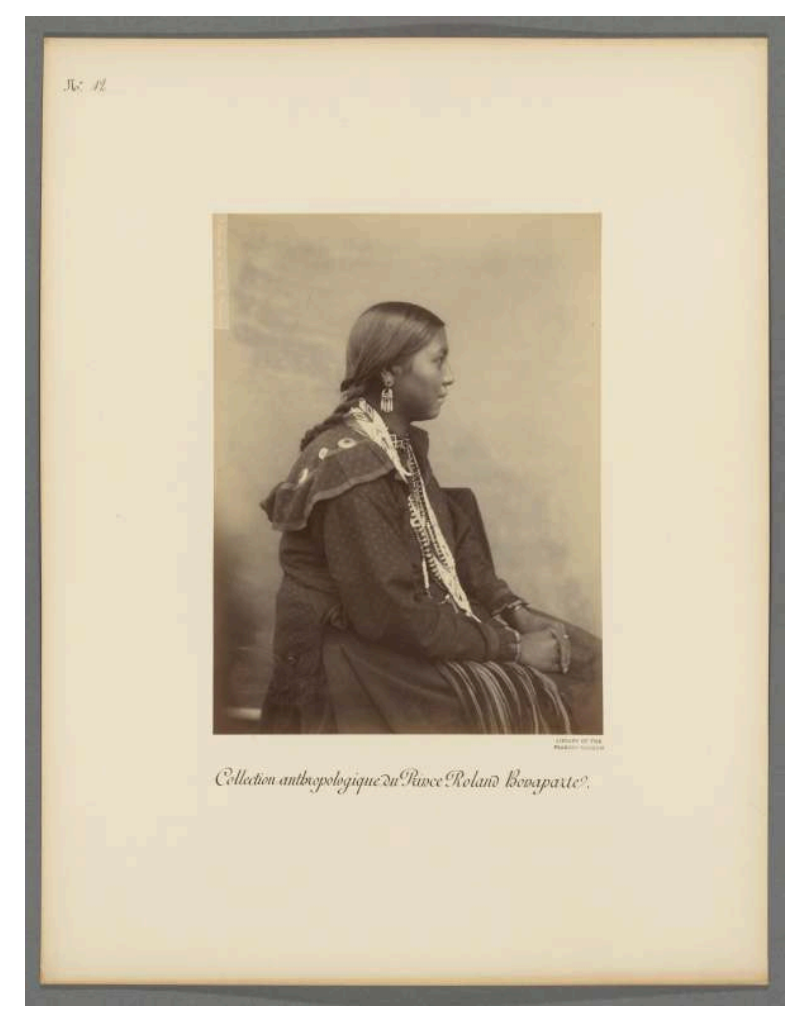

Prince Roland Bonaparte, Mnigh-di-tai, Peaux-Rouges (1884), albumen prints, Courtesy of Tozzer Library, Harvard University

This ongoing $U m o^{n} h o^{n}$ cultural adaptation and transformation is apparent in the photographs of women in the Bonaparte volume, such as that of Shoudé-Nasi's daughter, Mnigh-di-tai (Figure 8). By the mid-nineteenth century calico cloth replaced earlier fabrics in supplanting the hide that once comprised the material for women's clothing (Fletcher and La Flesche 355-356, 616). Garments remained in a similar style to those previously fashioned in buffalo skin, with a tunic often worn open at the sides over a skirt. Such pieces might also be embroidered and decorated with ribbon work (356). At American Indian boarding schools opened in the 1870s, and on the Omaha Reservation, officials taught women domestic labor such as sewing. At the latter, Quakers gave such instruction to female $U m o^{n} h o^{n}$ while in control of the agency (Milner II). Umo $\mathrm{Ho}^{n}$ women therefore made their own tunics and skirts, or dresses, from this training. Mnigh-di-tai sits in the photographs in such a calico top and skirt, embellished with ribbon work, hands folded in her lap and wearing a bandolier and single strings of beads; the symmetrical composition of this adornment mimicked by her neatly parted hair.

\section{Fixity / Mobility}

The Peaux-Rouges albums and their creation manifest dialectics between fixity and mobility central to $U m o^{n} h o^{n}$ experience during the early reservation and assimilation period. With the containment of Native nations in the U.S. onto reserves during the second half of the nineteenth century, photography served as a primary tool for imaging and making legible Indigenous peoples. Discourses surrounding photographic activities and American Indian communities often emphasized notions of cultural 
salvage in response to changing lifeways and supposedly vanishing populations. Not only did these practices occur within present-day national borders-with numerous projects funded by the U.S. government-they operated as actions and situations of exchange in the larger, interconnected Atlantic World. Bonaparte's photographic endeavor serves as one such example; his volume picturing the $U m o^{n} h o^{n}$ related to longer colonial histories of the French in North America and employs an approach rooted in period conceptions of racial fixing, inscription, and categorization.

The intellectual milieu in which Bonaparte operated and the mode of image-making he employed are exposed as framing constructs through aspects of mobility that characterize the photographs and their making. The "outtakes," which appear in the Peaux-Rouges maquette but are not included in the final volume, fracture the careful sequence of frontal and profile photographs that Bonaparte orchestrates, revealing the $U m o^{n} h o^{n}$ as integral agents in the staging of their own self-presentation. Moving from the controlled, or managed, mode of viewing in the ultimate volume to these outtakes, one breaks from the repetitive frame and sees evidence of the encounters that occurred in the exposition space during their production. As the Umo ${ }^{n} h o^{n}$ troupe traveled to Paris for the exhibition during allotment-which sought to fix individuals geographically and restructure Indigenous lifeways-their transatlantic traversal at this moment serves as another particularly pertinent aspect of their mobility. The group's travel at this time might be interpreted as both a form of resistance and an extension, albeit in a situation of more extreme power dynamics, of the longstanding entanglements they had by this period with the French.

Finally, although Bonaparte structures the album around a particular logic of reading, based on the enclosed introductory booklet and order of the prints, these mounted pictures are unbound, allowing for any number of new interpretations or reimaginings. Each of the photographic mounts is numbered, corresponding with the textual component Bonaparte included at the beginning of the volume. However, as these mounts were left loose, a greater fungibility and interpretive potentiality characterizes the project than that dictated by Bonaparte's guiding framework. The reader has the autonomy to reshuffle the order of the sitters, or isolate one or a group for display, rearranging the hierarchy and emphases Bonaparte created. After the creation and dissemination of the compilation, the readings, uses, and interactions with the pictures broadened to a spectrum of possibilities.

Based on the presence of period, as well as digitally repatriated, prints from this particular trip to Paris throughout the $U m o^{n} h o^{n}$ community, one can insinuate that tribal members have done this reinterpretation and reclamation from Bonaparte's narrative both historically and in the present-day. Local collections contain both a period print from Peaux-Rouges, as well as a studio portrait made during the 1883 Paris visit, and OTHRP acquired the entire series of Bonaparte's Umon $h o^{n}$ pictures as digitally repatriated copy prints in the late $1990 \mathrm{~s}^{23}$ These objects not only inhabit Umo ${ }^{n} h o^{n}$ based archives, which are centered on interpretation through tribal history and epistemologies, but appear in the public and domestic spaces of the reservation, where they accrue meaning as communal, familial, and social objects. The material format of these tomes allows for a freedom of reading and viewing, and their social lives and travel back to the Umon ${ }^{n} o^{n}$ demonstrates the possibility of re-appropriation and mobility, despite the initial framing discourses of creation. 


\section{BIBLIOGRAPHY}

Works Cited

BARTHE, Christine. "Les Omaha de Bonaparte: Exemples de photographie scientifique et de représentations iconographiques." Peaux-Rouges: Autour de la collection anthropologique du prince Roland Bonaparte. Ed. Benoît Coutancier. Paris : Photothèque du Musée de l'Homme, 1992, p. 64-73. BEETEM, Robert. “George Catlin in France: His Relationship to Delacroix and Baudelaire.” Art Quarterly, vol. 24, no. 2, summer 1961, p. 129-144.

BONAPARTE, Prince Roland. Peaux-Rouges. Saint-Cloud : Self-published, 1884.

BROCA, Paul et la Société d'anthropologie de Paris. Instructions générales pour les recherches anthropologiques. Paris : Victor Masson et Fils, 1865.

BURNS, Emily C. Transnational Frontiers: The American West in France. Norman : University of Oklahoma Press, 2018.

CATLIN, George. Catlin's Notes of Eight Years' Travels and Residence in Europe, with his North American Indian Collection. New York : Burgess, Stringer \& Co., 1848.

CONKLIN, Alice L. In the Museum of Man: Race, Anthropology and Empire in France, 1850-1950. New York : Cornell University Press, 2013.

CORDIER, Henri. “Le Prince Roland Bonaparte.” La Géographie, May 1924, p. 4-13.

COUTANCIER, Benoît. "Découvrir L'Autre au Jardin d'Acclimatation: Exhibitions ethnographiques et vulgarization scientifique (1877-1890)." Peaux-Rouges: Autour de la collection anthropologique du prince Roland Bonaparte. Ed. Benoît Coutancier. Paris : Photothèque du Musée de l'Homme, 1992, p. 34-47.

DELORIA, Philip. Indians in Unexpected Places. Lawrence : University Press of Kansas, 2004.

DIAS, Nélia. "Cultural Objects/Natural Objects: On the Margins of Categories and the Ways of Display." Visual Resources, vol. 13, 1997, p. 33-47.

--- “The Visibility of Difference: Nineteenth-Century French Anthropological Collections." The Politics of Display: Museums, Science, Culture. Ed. Sharon Macdonald. London : Routledge, 1998, p. 36-52.

“Dons au Musée." Bulletin de la Société d'anthropologie de Paris, $3^{\text {rd }}$ series, 7, March-April 1884.

EDWARDS, Elizabeth. “Professor Huxley's 'Well-considered Plan'.” Raw Histories: Photographs, Anthropology and Museums. Oxford : Berg, 2001, p. 131-156.

EVANS, Brad, and Aaron GLASS, editors. Return to the Land of the Head Hunters: Edward S. Curtis, the Kwakwaka'wakw and the Making of Modern Cinema. Seattle : University of Washington Press, 2014.

FLETCHER, Alice C., and Francis LA FLESCHE. Twenty-Seventh Annual Report of the Bureau of American Ethnology to the Secretary of the Smithsonian Institution, 1905-1906. Washington : Government Printing Office, 1911.

GITLIN, Jay. The Bourgeois Frontier: French Towns, French Traders, and American Expansion. New Haven : Yale University Press, 2010.

HAMY, Ernest Th. “Les Peaux-Rouge, indiens Omahas." Science et Nature, vol. 1, no. 1, 1883, p. 1-4. 
HARJO, Suzan S., editor. Nation to Nation: Treaties between the United States \& American Indian Nations. Washington, D.C. : National Museum of the American Indian, in Association with Smithsonian Books, 2014.

HASTINGS, Dennis (In'aska), and Margery COFFEY (Mi'on bathin ${ }^{n}$. “Completely Illustrated, Grandfather Remembers-Broken Treaties/Stolen Land: The Umo ${ }^{\mathrm{n}} \mathrm{ho}^{\mathrm{n}}$ Land Theft." Western Institute for Social Research, Berkeley. 2009. PhD dissertation.

HORTON, Jessica L. Art for an Undivided Earth: The American Indian Movement Generation. Durham : Duke University Press, 2017.

---. "Ojibwa Tableaux Vivants: George Catlin, Robert Houle, and Transcultural Materialism." Art History, vol. 39, no. 1, 2016, p. 124-151.

HOXIE, Frederick E. "Retrieving the Red Continent: Settler Colonialism and the History of American Indians in the U.S." Ethnic and Racial Studies, vol. 31, no. 6, 2008, p. 1153-1167.

HUYSSEN, Andreas. "Geographies of Modernism in a Globalizing World." New German Critique, no. 100,2007 , p. 189-207.

L'Illustration, 4 Aug. 1877.

LUBBERS, Klaus. "Strategies of Appropriating the West: The Evidence of Indian Peace Medals." American Art, vol. 8, no. 3/4, 1994, p. 79-95.

MANOUVRIER, L. “Sur les Peaux Rouges du Jardin d'Acclimatation." Bulletin de la Société d'anthropologie, $3^{\text {rd }}$ series, 8, 1885, p. 306-47.

MASSART, Émile. “Les Peaux-Rouges.” La Science Populaire, vol. 195, 7 Nov. 1883, p. 1413-1415.

MILNER II, Clyde A. With Good Intentions: Quaker Work Among the Pawnees, Otos and Omahas in the 1870s. Lincoln : University of Nebraska Press, 1982.

MORRIS-REICH, Amos. Race and Photography: Racial Photography as Scientific Evidence, 1876-1980. Chicago : The University of Chicago Press, 2016.

MOSES, L. G. Wild West Shows and the Images of American Indians, 1883-1933. Albuquerque : University of New Mexico Press, 1996.

"Nos gravures: Les peaux rouges au jardin d'acclimatation de Paris." L'Illustration, vol. 72, no. 2124,10 Nov. 1883 , p. 303-304.

ORTIZ, Fernando. Cuban Counterpoint: Tobacco and Sugar. 1947. Translated from the Spanish by Harriet de Onís. Durham : Duke University Press, 1995.

“Les Peaux-Rouges au Jardin d'Acclimatation.” Le Journal Illustré, vol. 46, 11 Nov. 1883, p. 365-366, 368.

PHILLIPS, Ruth B. “Taking the Local Seriously.” World Art, vol. 4, no. 1, 2014, p. 17-25.

POOLE, Deborah. “An Excess of Description: Ethnography, Race, and Visual Technologies.” Annual Review of Anthropology, vol. 34, 2005, p. 159-179.

PRATT, Mary Louise. Imperial Eyes: Travel Writing and Transculturation. London : Routledge, 1992.

RIALLE, Girard de. “Les Nubiens du Jardin d'acclimatation.” La Nature, vol. 2, no. 1, 1877, p. 198-203.

--- . “Les Esquimaux du Jardin d'acclimatation.” La Nature, vol. 2, no. 2, 1877, p. 390-95.

--- . “Les Peaux-Rouges au Jardin d'acclimatation.” La Nature, vol. 12, no. 2, 1884, p. 3-7. 
RIDINGTON, Robin, and Dennis HASTINGS (In'Aska). Blessing for a Long Time: The Sacred Pole of the Omaha Tribe. Lincoln : University of Nebraska Press, 1997.

SCARANGELLA MCNENLY, Linda. Native Performers in Wild West Shows: From Buffalo Bill to Euro Disney. Norman : University of Oklahoma Press, 2012.

SCHNEIDER, William H. "The Ethnographic Exhibitions at the Jardin Zoologique d'Acclimatation." Human Zoos: Science and Spectacle in the Age of Colonial Empires. Eds. Pascal Blanchard, Nicolas Bancel, Gilles Boëtsch, Éric Deroo, Sandrine Lemaire, and Charles Forsdick. Liverpool : Liverpool University Press, 2008, p. 142-150.

--- ."The Jardin d'Acclimatation, Zoos and Naturalization." Human Zoos: The Invention of the Savage. Eds. Pascal Blanchard, Gilles Boëtsch, and Nanette Jacomijn Snoep. Paris : Musée du Quai Branly, 2011, p. 130-144.

SEKULA, Allan. "The Body and the Archive." October, vol. 39, 1986, p. 3-64.

SHEA, John G. Discovery and Exploration of the Mississippi Valley: with the Original Narratives of Marquette, Allouez, Membré, Hennepin, and Anastase Douay. New York : Redfield, 1852.

SUNDER, John E. Joshua Pilcher, Fur Trader and Indian Agent. Norman : University of Oklahoma Press, 1968.

THORNE, Tanis C. The Many Hands of My Relations: French and Indians on the Lower Missouri. Columbia : University of Missouri Press, 1996.

THORP, Willard. "Cooper Beyond America." New York History, vol. 35, no. 4, October 1954, p. 522-539.

VIZENOR, Gerald. Manifest Manners: Narratives on Postindian Survivance. Lincoln : University of Nebraska Press, 1994.

\section{NOTES}

1. All translations were completed by the author.

I would like to thank the guest editors Emily Burns and Agathe Cabau for their invaluable feedback on this material both in the formation of this special issue and since 2012 when I began the project. I also wish to acknowledge the ongoing support and influence of OTHRP-Dennis Hastings, Margery Coffey, and Richard Chilton-in my study of $\mathrm{Umo}^{\mathrm{n}} \mathrm{ho}^{\mathrm{n}}$ history, representation, and material culture. Finally, I owe an immense gratitude to François Brunet, a generous mentor in pursuit of this work, whose feedback and support are-and will continue to be-profoundly missed.

As evidenced by the Register of incoming Cartes, Estampes et Dessins for the Société d'Anthropologie de Paris, now part of the Archives de la Société d'Anthropologie de Paris, the volume arrived on March 6, 1884. Listed in the Register as, No. d'Ordre 1848-1882. The April edition of the Bulletin de la Société d'Anthropologie also notes the object as part of, "a gift of a suite of photographic albums..." one for "les Indiens Peaux Rouges" that the Société d'Anthropologie visited ("Dons au musée," avril 1884, 285).

2. Although Bonaparte identifies all the members of the troupe as specifically Omaha and this title of the tribal community is still often used today by Euro-Americans, members of Omaha Tribal Historical Research Project (OTHRP)-the reservation-based group for history and culture -indicate that this term "is a corruption of $U m o^{n} h o^{n}$ in man-talk and $U m o^{n} h a^{n}$ in woman-talk." See OTHRP Director and Assistant Director's co-authored dissertation (Hastings and Coffey 18). 
As in many Native languages, there is a difference in the way that men and women speak. Following their lead, I use the term $U m o^{n} h o^{n}$ when referring to this culture and group of performers, which is an $U m o^{n} h o^{n}$ word and uses the correct pronunciation based on the International Phonetic Alphabet. This is the way that the name of the tribal community largely appears throughout the reservation today.

3. Archives de la Société d'Anthropologie de Paris, 9, série C: Candidature, démission, absences; no. 4, 1884-1894, no. 3001 .

4. Bonaparte's album may have been disseminated beyond the Euro-American world, however, this is the context of all of the versions I have located.

5. "Transcultural" originates from the term "transculturation," first devised in the 1940s by Cuban sociologist Fernando Ortiz in his description of Afro-Cuban culture. The word refers to the coming together and transformation of distinct cultures, especially in situations of asymmetrical power relations such as colonialism, in which new objects, practices, beliefs, and identities emerge as a result of this two-way contact and merging.

6. As historian William H. Schneider indicates, these animals were from Somalia and the Sudan in the Horn of Africa (142).

7. As L'Illustration describes on August 4, 1877, "crowds flock in unhesitatingly" and "everyday, visitors abound." Schneider notes that following the first year of these shows in 1877, visitors increased by over 200,000 people and by 1878 , annual attendance at the Jardin d'Acclimatation reached a record number of one million people (Schneider, 2008 142; Schneider, 2011 132).

8. The emergence of this exhibition culture at the Jardin d'Acclimatation was part of the increase in the display of groups of living peoples at this time on both sides of the Atlantic, which coincided with the developing field of anthropology in its national variants and the discourses of race and larger imperialist political frameworks that supported them. Singular groups or shows came to European capitals earlier in the century, such as the South African woman Saartjie Baartman, who was toured through London and Paris between 1810 and 1815, but Carl Hagenbeck, an animal merchant, first commercialized the ethnographic show on a major scale in Germany in 1874. He organized not only regular exhibitions of diverse troupes of people but toured them widely, and the Jardin d'Acclimatation in Paris followed suit with a similar type of exhibition in 1877. As opposed to this exposition culture, which grew out of the animal trade in Europe and was linked in France specifically to sociétés savantes culture and a practice of physical anthropology, in the U.S. over the second half of the nineteenth century anthropological practice served as a government science, linked largely to the Smithsonian Institution. Influenced heavily by ideas of social evolutionary theory, the Smithsonian contributed numerous ethnographic exhibitions to World's Fairs before commercial enterprises such as Buffalo Bill's Wild West took off in the 1880s.

9. The fact that these tepees were $U m o^{n} h o^{n}$-built, and the materials most likely brought by the troupe, was suggested through conversation with Dennis Hastings, Director of OTHRP during a visit to the Omaha Reservation in October 2015.

10. These debates are attested to by legal correspondence in the Archives Municipales de Neuillysur-Seine, 344, Jardin d'Acclimatation.

11. After this point the venue started to cater more heavily to popular audiences.

12. Archives de la Société d'Anthropologie de Paris, 8, série B (1) Diplôme, 2698. Here SaintHilaire refers to a second troupe of Inuit performers at the garden in 1881. Italics added for emphasis of the oppressive, patronizing language of the period.

13. Along with other members of period French anthropological circles, Bonaparte's use of the exposition space as a research terrain is especially interesting given that a practice of ethnographic fieldwork did not develop in French anthropology until the 1920s, under the direction of Marcel Mauss and Paul Rivet (Conklin 1-18). 
14. This maquette, in which the frontal and profile photographs of each sitter appear affixed side-by-side to the same long horizontal mounts with hand written annotations above, in the manner of working out the layout of the volume, is housed in the Archives de la Société de Géographie de Paris, Bibliothèque nationale de France, SG Wf-348.

15. These physical and social descriptors include, among other details, age and marital status. $U m o^{n} h o^{n}$ is not a written language, and although there have been attempts to write it down; there is no standardized orthographic system. As a result, as Bonaparte or his assistant at the Jardin d'Acclimatation transcribed the names of the $U m 0^{n} h o^{n}$, they likely recorded them phonetically, and the results are one of multiple examples of the way that things were imaginatively reinterpreted as the two cultures came together.

16. The National Anthropological Archives of the Smithsonian Institution holds two copies of Peaux-Rouges, one originally sent to the Anthropological Society of Washington, D. C. and the other to the Smithsonian Institution. The gift letter in the former, signed by Bonaparte's Secrétaire particulier, M. Bonnaud, is undated, while that in the latter dates to May 12, 1884.

17. The copy of Peaux-Rouges that Bonaparte gave to the Broca Library at the Société d'Anthropologie retains the number ninety-three.

18. Hastings and Coffey note that there are many French surnames, historically and today, among the tribal community. These include those such as Fontenelle, La Flesche, Saunsoci, Cayou, and Lyons (98).

19. This history helps explain the impetus of the $U m o^{n} h o^{n}$ troupe to make this trip to Paris, as discussed with Coffey and Hastings since 2015.

20. These portraits were made by photographers such as Antonio Zeno Shindler, Alexander Gardner, and Charles Milton Bell, among other studio practitioners in the capital, and disseminated both domestically and internationally in album form in Ferdinand V. Hayden and William Henry Jackson's volumes, Photographs of North American Indians based on a corresponding textual catalogue they compiled, Descriptive Catalogue of Photographs of North American Indians (1877).

21. Fletcher arrived in May of 1883 to begin her allotment work with La Flesche. La Flesche would collaborate with Fletcher for over two decades in the creation of the Twenty-Seventh Annual Report of the Bureau of American Ethnology, The Omaha Tribe (1905-6). The exhaustive work was the first major ethnography coauthored between an outside fieldworker, Fletcher, and a member of the Native community in question, La Flesche.

22. Scottish-Irish American novelist Thomas Mayne Reid also wrote texts set in the American West that enjoyed popularity in France.

23. The period print from Peaux-Rouges is in the collection of the John G. Neihardt Center in Bancroft, NE, and the studio photograph is in the collection of OTHRP. As part of his initiative the "Umon $h o^{n}$ Historical Picture Project" OTHRP Director Hastings requested the entire Peaux-Rouges series from the Musée de l'Homme, now the Musée du Quai Branly in the 1990s.

\section{ABSTRACTS}

This article analyzes the photographic album Peaux-Rouges compiled by Prince Roland Bonaparte in 1884. This album focuses on a troupe of visiting $U m 0^{n} h o^{n}$ (Omaha) Indians in Paris and presents them through tribally specific history and memory. Created within the emergent discourses of 
nineteenth-century French anthropology grounded in notions of the racial type, the volume has largely been contextualized in these conceptions of human difference and developing scientific cultures. Here, however, the author shifts focus to the experiences of the pictured sitters, examining the photographic exchange embodied in the work as a specific moment in ongoing settler colonial relationships between the $U m o^{n} h o^{n}$ and European, followed by Euro-American, colonizers. The text explores how local Umo $h o^{n}$ meanings related to these pictures intersect with, and complicate, the discourses surrounding their initial making in cosmopolitan networks in Paris. This reading argues that visual references to transcultural exchange and performance in Peaux-Rouges, as well as the material circulation histories of the included photographs over time, disrupt its initial framing based on presumptions of fixed, racial identity.

Cet article analyse l'album photographique Peaux-Rouges compilé par le prince Roland Bonaparte en 1884. L'album suit une troupe de visiteurs indiens $U m o^{n} h o^{n}$ (Omaha) à Paris à travers leur histoire et leur mémoire tribales. Produit des discours émergents de l'anthropologie française du $\mathrm{XIX}^{\mathrm{e}}$ siècle reposant sur des notions de type racial, le volume a été lu comme illustrant les conceptions de la différence humaine et du développement des cultures scientifiques. Ici, cependant, l'auteur se concentre sur l'expérience des personnes photographiées, et comprend l'échange photographique comme un moment particulier des relations coloniales entre les $U m o^{n} h o^{n}$ et les Européens (devenus ensuite colonisateurs Euro-américains). L'article explore comment les significations $U m o^{n} h o^{n}$ locales véhiculées par les images croisent et compliquent les discours liés à leur création initiale au sein des réseaux cosmopolites à Paris. Cette lecture montre comment dans Peaux-Rouges, les références visuelles aux échanges transculturels et à la performance, mais aussi la circulation matérielle des photographies au fil du temps, troublent la lisibilité de son cadrage initial fondé sur des présomptions d'identité raciale figée.

\section{INDEX}

Mots-clés: Amérindiens, anthropologie, photographie ethnographique, autochtone, Jardin d'Acclimatation, Omaha / Umonhon; performance, « race ", transculturalité

Keywords: American Indians, anthropology, ethnographic photography, Indigenous, Jardin d'Acclimatation, Omaha / Umonhon, performance, race, transculturality

\section{AUTHOR}

EMILY L. VOELKER

Vassar College

evoelker@vassar.edu 